\title{
BIOGAS PRODUCTION FROM GOAT AND CHICKEN MANURE IN MALAYSIA
}

\author{
HANAFIAH, M. M. ${ }^{1,{ }^{*}}$ - MOHAMED ALI, M. Y. ${ }^{1}-$ ABDUL AZIZ, N. I. H. ${ }^{1}-$ ASHRAF, M. A. $^{2}$ \\ - HALIM, A. A. ${ }^{1}-$ LEE, K. E. ${ }^{3}-$ IDRIS, M. ${ }^{1}$ \\ ${ }^{1}$ School of Environmental and Natural Resource Sciences, Faculty of Science and Technology, \\ Universiti Kebangsaan Malaysia, 43600 UKM Bangi, Selangor, Malaysia \\ ${ }^{2}$ Department of Environmental Science and Engineering, School of Environmental Studies, \\ China University of Geosciences, 430074 Wuhan, P. R. China \\ ${ }^{3}$ Institute for Environment and Development (LESTARI), Universiti Kebangsaan Malaysia, \\ 43600 Bangi, Selangor, Malaysia \\ *Corresponding author \\ e-mail: mhmarlia@ukm.edu.my; phone:+60-389-215-865; fax:+60-389-253-357
}

(Received 22 $2^{\text {nd }}$ Jul 2016; accepted $9^{\text {th }}$ Nov 2016)

\begin{abstract}
The aims of this study were, i) to determine the biophysical characteristics of the substrate using Chemical Oxygen Demand (COD), nutrient, heavy metal, Carbon to Nitrogen and Ammonianitrogen content analyses, and ii) to compare the biogas production between goat dung and chicken dung using industrial inoculum and traditional bokashi as catalyst. Bio-Methane Potential (BMP) test was used to measure biogas production in mesophilic condition for time duration of 20 days. The goat's dung produced $2141 \mathrm{~mL}$ of biogas, higher than $1885.7 \mathrm{~mL}$ that of chicken dung using industrial inoculum . It was found that goat dung and chicken dung can be used as an energy source in a small scale industry as compared to the traditional bokashi where no methane gas was produced from the substrates.
\end{abstract}

Keywords: industrial inoculum, traditional bokashi, biophysical characteristic, Bio-Methane Potential test, livestock production

\section{Introduction}

In 2012, the number of livestock for goats and chickens in Malaysia was estimated around 505 and 208 millions, respectively. The abundant feces may release nitrate and ammonia gas causing water pollution, odour pollution and health problems to human beings. The alternative measure to manage this problem is to use these feces as raw materials in biogas production. Biogas consists of a mixture of methane gas, hydrogen gas, carbon dioxide and other gases resulting from decomposition of organic matter by anerobic bacteria in the absence of oxygen. Biomass is defined as ecologically dried materials from living organisms that present in certain periods for each unit of earth surface (Manyi-Loh et al., 2013). Biomass energy is defined as an energy from the plants and raw materials from industrial and municipal waste (White, 1981). The waste from agriculture and animals excrement are among the biomass sources could be converted to energy which are cheaper and renewable energy sources (Zheng et al., 2011). Through anaerobic digestion process, biomass turns to biogas which is a mixture of methane $\left(\mathrm{CH}_{4}\right)$ and carbon dioxide $\left(\mathrm{CO}_{2}\right)$ gases that used to produce energy (Yadvika et al., 2004). Biogas consists of methane gas (45-70\%), carbon dioxide (25-40\%), hydrogen $(<1 \mathrm{ppm})$, nitrogen $(<3 \mathrm{ppm})$ and hydrogen sulphide $(<10 \mathrm{ppm})$. The organic material decomposition through several stages namely hydrolysis, acidogenesis, acetogenesisand methanogenesis. Each stage need different anaerobic bacteria such as 
Lactobacillus sp., Clostridium sp., Methanobacter sp. and Aminobacterium sp. to digest the biomass.

Animal husbandry increases rapidly as the human population increases in Malaysia. The demand for mutton and chicken eggs leads to the increase in goat and chicken farms which cause excessive faecal waste dumping. According to Wang et al., (2012), a chicken may produce up to $59 \mathrm{~kg}$ dung in a year and a goat could averagely produce 0.7 $\mathrm{kg}$ dung in a day. These animal excrement leads to water and odour pollutions because of hydrogen sulfide $\left(\mathrm{H}_{2} \mathrm{~S}\right)$ gas released from the faeces (Oyewole, 2010). In Malaysia, oil palm, woods and agro-industry waste are main biomass sources being used in factory's processing activities and generating power. Animal excrement is an example of agro-industry waste that can be used as biomass to produce biogas. Goat dung (GD) and chicken dung (CD) are rich in organic content as GD have high nitrogen content and stable during fermentation process. Besides that, $C D$ have high nutrient content which is suitable for anaerobic digestion. In biogas production, using substrate as the only feeder in anaerobic digestion produces biogas in small amount of biogas. Therefore, large quantity of substrate is needed to produce large amount of biogas for commercial usage. Inoculum acts as a catalyst to increase total production of biogas (Bruni et al., 2010). Inoculum consists of microbs tends to digest organic content in the substrates efficiently.

The objective of this study was to determine production of biogas from animal manures, i.e. goat dung and chicken dung using two different types of inoculum (industrial inoculum and traditional bokashi). Industrial inoculum was produced by a local company and traditional bokashi was produced from organic material using effective microorganisms (EM) concept introduced by Prof. Dr. Teruo Higa.

\section{Research methods}

\section{Sampling stations}

The sample for GD was taken from a private goat's farm located at Asahan, Melaka and the sample for CD was taken from Q1 Poultry Farms Sdn Bhd's farm located at Pajam, Mantin, Negeri Sembilan. All the excrements were kept in airtight plastic bags and the plastic bags were stored at $4{ }^{\circ} \mathrm{C}$ in a airtight container to preserve the freshness of samples and slow down the natural bacteria decomposition.

\section{Apparatus and operation}

The dried mass (DM) and organic dried mass (ODM) were measured. The organic loading rate (OLR) was calculated to determine the amount of substrate needed to be digested inside the $1 \mathrm{~L}$ digester bottle. The OLR was fixed at $4 \mathrm{~g} / \mathrm{L}$. Each substrate was mixed with $500 \mathrm{~mL}$ industrial inoculum as catalyst before being placed inside the BioMethane Potential machine. The experiment was conducted in three replicates. The digester bottle was injected with $\mathrm{N}_{2}$ gas and released for three times to remove $\mathrm{O}_{2}$ to maintain the anaerobic condition in the digester bottle at the beginning of experiment. The temperature was controlled at mesophilic temperature $\left(37^{\circ} \mathrm{C}\right)$ by water bath machine and reading was taken for 20 days. The acid solution in the eudiometer tube showed the amount of biogas produced. The experiment was repeated using traditional bokashi as catalyst. 


\section{Analytical methods}

Wet digestion method (ISO 11466, 2002) was used to extract GD and CD. HACHReactor Digestion Method was used to measure chemical oxygen demand (COD). Heavy metal content was determined using Inductively Coupled Plasma-Optical Emission Spectrometry (ICP-OES). The protein content was determined using in-house method No. STP/Chem/A03 based on AOAC $16^{\text {th }}$ Edi. 981.10. Fat content was determined using in-house method No. STP/Chem/A02 based on AOAC $16^{\text {th }}$ Edition 991.36. The carbohydrate content was measured using in-house method No. STP/Chem/A06. The ash content was calculated using in-house method No. STP/Chem/A05 based on AOAC $16^{\text {th }}$ Edi. 923.03. Moisture content was determined inhouse method No. STP/Chem/A04 based on AOAC $16^{\text {th }}$ Edi. 950.46. The energy content was calculated using in-house method No. STP/Chem/A01 and the nitrogen content was measured using in-house method No. STP/Chem/A03 based on AOAC $16^{\text {th }}$ Edi. 981.10. The ammonia-nitrogen content was measured using Nessler method. The $\mathrm{C} / \mathrm{N}$ ratio was determined using $\mathrm{CHNS}$ analyzer machine. Biogas composition was determined using Binder's COMBIMASS ${ }^{\circledR}$ Portable Gas Analyzer GA-m5.

\section{Results and discussion}

Table 1 shows that DM for CD is higher than that of GD. It also shows the water content in GD is higher than that of CD. CD could have water content up to $76 \%$ but nutrition factor, health condition and probability of excrement exposed to moisture could change the DM (Pognani et al., 2012). ODM mesures the organic content in excrement as $80 \%$ of methane gas produced from ODM of a substrate. ODM of GD is $87.07 \%$ which is higher than that of CD $(65.28 \%)$. Total substrate needed in the digester (A) was calculated using this formula:

$$
\mathrm{A}=\frac{0.5 \times \text { OLR }\left(\frac{4 \mathrm{~S}}{\mathrm{~L}}\right)}{\operatorname{DMXODM}}
$$

The organic loading rate (OLR) was fixed at $4 \mathrm{~g} / \mathrm{L}$ for $1 \mathrm{~L}$ digester.

Table 1. Laboratory analyses results

\begin{tabular}{lcc}
\hline Analyses Parameter & Goat Dung & Chicken Dung \\
\hline DM (\%) & $63.85 \pm 0.65$ & $76.78 \pm 1.5$ \\
ODM (\%) & $87.07 \pm 0.2$ & $65.28 \pm 2.3$ \\
Total substrates needed in digester (g) & 3.68 & 4.04 \\
Chemical Oxygen Demand (COD) (g/L) & $1.93 \pm 0.06$ & $2.80 \pm 0.14$ \\
Expected methane gas production (L) & 0.67 & 0.98 \\
Ammonia-nitrogen test (g/L) & 1.30 & 7.30 \\
Carbon:Nitrogen Ratio (C:N) & $12: 1$ & $8: 1$ \\
\hline
\end{tabular}

COD determines the amount of organic content in a substrate. Organic material will be oxidised into carbon dioxide $\left(\mathrm{CO}_{2}\right)$ and water $\left(\mathrm{H}_{2} \mathrm{O}\right)$ in acidic condition. COD of CD is higher than that of GD. According to Heindrich et al. (2011), a gram of COD tends to produce $0.35 \mathrm{~L}$ of methane gas. GD is expected to produce $0.67 \mathrm{~L}$ methane gas and $0.98 \mathrm{~L}$ for $\mathrm{CD}$. The ammonia-nitrogen content of $\mathrm{CD}$ is higher than 
that of GD as ammonia concentrations between 0.5 to $1 \mathrm{~g} / \mathrm{L}$ are beneficial to biogas production and the concentration more than $15 \mathrm{~g} / \mathrm{L}$ will retard the production of biogas (Surendra et al., 2013). Low C:N ratio triggers ammonia production and could increase $\mathrm{pH}$ more than 8.5 which is harmful to methanogenic bacteria. High $\mathrm{C}: \mathrm{N}$ ratio causes shortage in nitrogen which can be digested rapidly by methanogen and decrease in methane production (Khalid et al., 2011). Ideal C:N ratio is ranged from 20:1 to 30:1 (Pang et al., 2008).

Table 2 shows the nutrient analysis conducted on GD and CD. Protein is a combination of amino acids with hydrolysed peptide bonds by proteases. Amino acid forms ammonia $\left(\mathrm{NH}_{3}\right)$, carbon dioxide $\left(\mathrm{CO}_{2}\right)$ and hydrogen gas $\left(\mathrm{H}_{2}\right)$ and its high concentration causes ammonia concentration increase and affect methanogenic bacteria growth (Isci and Demirer, 2007). Fat contains fatty acids which are organic acids that increase biogas productions. Carbohydrate's structure forms from carbon, hydrogen and oxygen in a ratio of 1:2:1, respectively. GD'S carbohydrate is higher than that of CD. Ash contains inorganic material such as mineral and salt which can lower the energy content in substrate. Energy content helps in new anaerobic bacteria growth.

Table 2. The nutrient analysis

\begin{tabular}{lcc}
\hline Analyses (g/kg) & Goat Dung & Chicken Dung \\
\hline Protein & 0.83 & 0.69 \\
Fat & 0.18 & 0.05 \\
Carbohydrate & 4.73 & 0.51 \\
Ash & 0.6 & 0.86 \\
Moisture & 6.34 & 7.89 \\
Nitrogen & 0.13 & 0.11 \\
Energy (kJ) & 1004 & 223 \\
\hline
\end{tabular}

Substrate with moisture between 36 to $99 \%$ tends to increase biogas production from the substrate up to $67 \%$ (Hancsok et al., 2011). Production of amino acids, protein and nucleic acid need nitrogen as nitrogen is converted to ammonia to neutralise volatile acids produced by bacteria and maintain a neutral medium for anaerobic bacteria to growth (Wang et al., 2014).

Table 3 shows the heavy metals content in goat dung and chicken dung. Calcium concentration more than $0.30 \mathrm{~g} / \mathrm{L}$ is beneficial and concentration as high as $70.00 \mathrm{~g} / \mathrm{L}$ does not result any negative impact on biogas production (Abbasi et al., 2012). Lithium can be detected on biogas slurry and no negative effect on the present of Lithium (Anderson et al., 1991).

Table 3. Heavy metals analysis

\begin{tabular}{lcc}
\hline Elements & Goat Dung & Chicken Dung \\
\hline Calcium $(\mathrm{Ca})$ & 1.48 & 10.50 \\
Lithium $(\mathrm{Li})$ & 0.21 & 0.21 \\
Magnesium $(\mathrm{Mg})$ & 8.10 & 5.53 \\
\hline
\end{tabular}


Magnesium is able to shorten the time taken for substrate to decompose and increase biogas production if magnesium content is more than 0.03 to $0.20 \mathrm{~g} / \mathrm{L}$. However, magnesium concentration more than $10.00 \mathrm{~g} / \mathrm{L}$ will retard biogas production.

Fig. 1 shows the combinations of biogas production from the GD and CD using both catalysts, i.e. industrial inoculum and traditionalbokashi. Using industrial inoculum, GD produces $2141 \mathrm{~mL}$ of biogas and $1885.7 \mathrm{~mL}$ for $\mathrm{CD}$. The $\mathrm{pH}$ reading for substrate using industrial inoculum shows decrease toward neutral $\mathrm{pH} 6.8$ and $\mathrm{pH} 7.2$ is the ideal $\mathrm{pH}$ for anaerobic digestion (Yadvika et al. 2004). By using traditional bokashi, GD produces $1134.5 \mathrm{~mL}$ of biogas and $1118 \mathrm{~mL}$ for $\mathrm{CD}$. The $\mathrm{pH}$ shows acidic condition which is not suitable for anaerobic digestion. The $\mathrm{pH}$ readings are shown in Table 4.

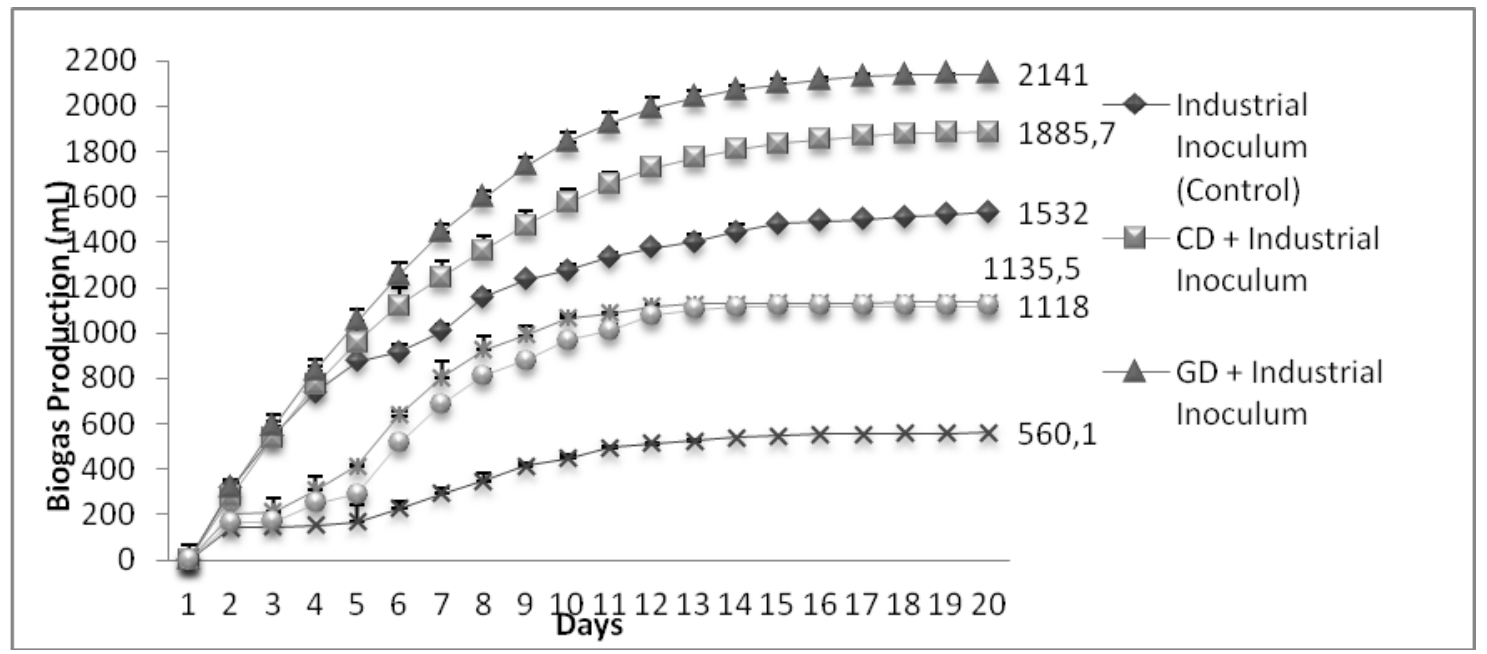

Figure 1. Comparison graph of biogas production from GD and CD using industrial inoculum and traditional bokashi

Table 4. The $p H$ reading in digester bottles

\begin{tabular}{lcccc}
\hline Type of Inoculum & \multicolumn{2}{c}{ Day 1 } & \multicolumn{2}{c}{ Day 20 } \\
& GD & CD & GD & CD \\
\hline Industrial Inoculum & $7.83 \pm 0.08$ & $7.83 \pm 0.07$ & $7.64 \pm 0.08$ & $7.75 \pm 0.08$ \\
Traditional Bokashi & $3.91 \pm 0.06$ & $3.86 \pm 0.08$ & $3.55 \pm 0.05$ & $4.52 \pm 0.52$ \\
\hline
\end{tabular}

Using industrial inoculum, 3.68g of GD is able to produce $2141 \mathrm{~mL}$ of biogas, $29.5 \%$ or $631.59 \mathrm{~mL}$ is methane gas. Theoretically, $1000 \mathrm{~L}$ methane gas produces $9.94 \mathrm{kWj}$ of electrical energy (Angelidaki, 1994). Therefore, $0.0063 \mathrm{kWj}$ could be generated from these methane gases and a kilogramme of GD is able to produce $1.71 \mathrm{kWj}$ of energy. Methane gas produced by $4.04 \mathrm{~g}$ of $\mathrm{CD}$ is $569.48 \mathrm{~mL}$ or $30.2 \%$ from $1885.7 \mathrm{~mL}$. Energy could be produced by CD is $0.0057 \mathrm{kWj}$ or $1.41 \mathrm{kWj}$ using a kilogramme of $\mathrm{CD}$. However, traditional bokashi is not capable in producing methane gas although still having biogas production. Traditional bokashi produces high amount of carbon dioxide $\left(\mathrm{CO}_{2}\right)$, hydrogen sulfide $\left(\mathrm{H}_{2} \mathrm{~S}\right)$ and ammonia gas $\left(\mathrm{NH}_{3}\right)$ and causing methanogenic bacteria growth retarded. 


\section{Conclusions}

Biogas treatment is the best solution to overcome problems caused by the abundance of animal excrement especially goat dung and chicken dung. Both excrements have potential bio-physical characteristic in producing biogas. As these excrements are used as feeder in an anaerobic digestion, the organic content can be decomposed to form biogas. Inoculum as catalyst is crucial to speed up and increase the biogas production by the substrates. Industrial inoculum contains anaerobic bacteria that can increase biogas production and traditional bokashi is not recommended as catalyst as no methane is produced. Water and odour pollutions could be avoided as the excrements can be used as a feeder. The waste from the digester chamber could be reused as fertilizer for plants as the nutrient content of the excrement decomposed and easier for the plant to absorb the nutrient.

Acknowledgements. We gratefully acknowledge the use of facilities within the Tasik Chini Research Centre (PPTC), UKM. Marlia Mohd Hanafiah was financed by research grants: FRGS/2/2013/STWN01/UKM/03/1 and TD-2014-012.

\section{REFERENCES}

[1] Abbasi, T., Sanjeevi, R., Makhija, M., Abbasi, S. A. (2012): Role of vitamins B-3 and C in the fashioning of granules in uasb reactor sludge. - Appl Biochem Biotechnol 167: 2348-357.

[2] Al-Masri, M. R. (2001): Changes in biogas production due to different ratios of some animal and agricultural wastes. - Bioresource Technology 77: 197-100.

[3] Anderson, G. K., Campos, C. M. M., Chernicharo, C. A. L., Smith, L. C. (1991): Evaluation of the inhibitory effects of lithium when used as a tracer for anaerobic digesters. - Water research 25: 7755-760.

[4] Angelidaki, I., Ahring, B. K. (1994): Anaerobic thermophilic digestion of manure at different ammonia loads: effect of temperature. - Water Res 28: 3727-731.

[5] Bruni, E., Jensen, A. P., Angelidaki, I. (2010): Comparative study of mechanical, hydrothermal, chemical and enzymatic treatments of digested biofibers to improve biogas production. - Bioresour Technol 101: 228713-8717.

[6] Hancsok, J., Baladincz, P., Kasza, T., Kovacs, S., Toth, C., Varga, Z. (2011): Biogas oil production from waste lard. - J Biomed Biotechnol 2011: 384184.

[7] Heidrich, E. S., Curtis, T. P., Dolfing, J. (2011): Determination of the internal chemical energy of wastewater. - Environ Sci Technol 45: 2827-832.

[8] Hosseini, S. E., Wahid, M. A., Aghili, N. (2013): The scenario of greenhouse gases reduction in Malaysia. - Renewable and Sustainable Energy Reviews 28: 400-409.

[9] Isci, A., Demirer, G. (2007): Biogas production potential from cotton wastes. Renewable energy 32: 5750-757.

[10] Khalid, A., Arshad, M., Anjum, M., Mahmood, T., Dawson, L. (2011): The anaerobic digestion of solid organic waste. - Waste Management 31: 1737-1744.

[11] Li, Y., Park, S. Y., Zhu, J. (2011): Solid-state anaerobic digestion for methane production from organic waste. - Renewable and sustainable energy reviews 15: 1821-1826.

[12] Manyi-Loh, C. E., Mamphweli, S. N., Meyer, E. L., Okoh, A. I., Makaka, G., Simon, M. (2013): Microbial anaerobic digestion (Bio-digesters) as an approach to the decontamination of animal wastes in pollution control and the generation of renewable energy. - Int J Environ Res Public Health 10: 4390-4417. 
[13] Moore, P. A., Daniel, T. C., Sharpley, A. N., Wood, C. W. (1995): Poultry manure management: Environmentally sound options. - Journal of Soil and Water Conservation 50: 321-327.

[14] Oyewole, O. A. (2010): Biogas production from chicken droppings. - Science World Journal 5: 11-14.

[15] Pang, Y. Z., Liu, Y. P., Li, X. J., Wang, K. S., Yuan, H. R. (2008): Improving biodegradability and biogas production of corn stover through sodium hydroxide solid state pretreatment. - Energy \& Fuels 22: 2761-2766.

[16] Rasi, S., Veijanen, A., Rintala, J. (2007): Trace compounds of biogas from different biogas production plants. - Energy 32: 1375-1380.

[17] Surendra, K. C., Takara, D., Jasinski, J., Khanal, S. K. (2013): Household anaerobic digester for bioenergy production in developing countries: Opportunities and Challenges. - Environ Technol 34: 1671-1689.

[18] Wang, X., Yang, G., Feng, Y., Ren, G., Han, X. (2012): Optimizing feeding composition and carbon-nitrogen ratios for improved methane yield during anaerobic co-digestion of dairy, chicken manure and wheat straw. - Bioresour Technol 120: 78-83.

[19] White, P. L. (1981): Contempo '81. Foods and Nutrition. - JAMA 245: 2239-2241.

[20] Yadvika, S., Sreekrishnan, T. R., Kohli, S., Rana, V. (2004): Enhancement of biogas production from solid substrates using different techniques - A review. - Bioresour Technol 95: 11-10.

[21] Zheng, Y., Yates, M., Aung, H., Cheng, Y. S., Yu, C., Guo, H., Zhang, R., Vandergheynst, J., Jenkins, B. M. (2011): Influence of moisture content on microbial activity and silage quality during ensilage of food processing residues. - Bioprocess Biosyst Eng 34: 987-995. 